Article

\title{
Socioeconomic Indicators for the Evaluation and Monitoring of Climate Change in National Parks: An Analysis of the Sierra de Guadarrama National Park (Spain)
}

\author{
Iván López ${ }^{1, *}$ and Mercedes Pardo 2 (10) \\ 1 Department of Psychology and Sociology, University of Zaragoza, c/Pedro Cerbuna, 12, \\ 50009 Zaragoza, Spain \\ 2 Department of Social Analysis, University Carlos III of Madrid, c/Madrid, 126, 28903 Getafe, Spain; \\ mercedes.pardo@uc3m.es \\ * Correspondence: ivalopez@unizar.es; Tel.: +34-976-8765-54578
}

Received: 27 November 2017; Accepted: 8 February 2018; Published: 12 February 2018

\begin{abstract}
This paper analyzes the importance of assessing and controlling the social and economic impact of climate change in national parks. To this end, a system of indicators for evaluation and monitoring is proposed for the Sierra de Guadarrama National Park, one of the most important in Spain. Based on the Driving forces-Pressure-State-Impact-Response (DPSIR) framework, the designed system uses official statistical data in combination with data to be collected through ad hoc qualitative research. The result is a system of indicators that monitors the use of natural resources, the demographic evolution, economic activities, social interactions, and policies. Adapted to different contexts, these indicators could also be used in other national parks and similar natural protected areas throughout the world. This type of indicator system is one of the first to be carried out in Spain's national parks. The result is a system that can be useful not only in itself, but also one that can catalyze climate change planning and management of national parks.
\end{abstract}

Keywords: socioeconomic indicators; national parks; climate change; sustainable development; Sierra de Guadarrama; Spain

\section{Introduction}

Anthropogenic climate change, which is produced by greenhouse gas emissions from human activities added to natural climate variability [1], is one of the most serious problems of global environmental change faced by contemporary societies [2].

The need to identify the current and foreseeable impacts of climate change as well as its mitigation and adaptation presents challenges in scientific, political, economic and social spheres [2]. Among these challenges is addressing the potential impacts on national parks [3].

National parks are privileged spaces for monitoring climate change impacts [4-7]. As they are protected spaces in their biophysical characteristics and limited in their socioeconomic activities, they are easier to control than other spaces that are subjected to social and economic dynamics. In addition, high mountain areas - as is the case of the Sierra de Guadarrama National Park-are a good indicator of the possible effects of climate change on other parts of the planet, as they are particularly sensitive to global environmental changes $[8,9]$.

Consequently, the identification, evaluation and monitoring of the impact of climate change on the park values (biological, cultural, etc.) is an important task for science and for identifying appropriate management actions [3,6,10,11]. 
There is already experience in monitoring systems with indicators related to biophysical conservation and evaluation of conservation management [12-16] as well as the impact of global environmental change on national parks $[4,6,7,17]$. However, monitoring the social systems that are both producing climate change and being impacted by climate change in national parks is much scarcer [3,18-21].

There are fifteen national parks in Spain, and for only two of these-Picos de Europa and Sierra de Guadarrama-has a system of indicators for the assessment and monitoring of the socioeconomic impact of climate change been developed. Given the recent creation of these monitoring systems, they have not yet collected enough time-series of data to detect trends in any socioeconomic indicators.

In this paper, we present the system of indicators developed for the Sierra de Guadarrama National Park. We first describe the special biophysical and cultural characteristics of the Sierra de Guadarrama. Secondly, we highlight the relevance of a system of socioeconomic indicators to evaluate and monitor climate change in the Sierra de Guadarrama National Park. Then, we explain the methodology used to develop the indicator system. Finally, we present the selected indicators, the conclusions, and some lines of discussion.

\subsection{Sierra de Guadarrama: Object of Desire for Kings, Nobles, Clergymen and Novelists, Since the Middle Ages}

The Sierra de Guadarrama National Park occupies 33,960 hectares, and is located in the mountain range of the Central System (Figure 1), forming part of the natural division between the northern and southern plateaus that make up the center of the Iberian Peninsula (Spain and Portugal). In addition, its peripheral protection zone is $62,687.26$ hectares (this has its own legal regime, designed to promote the values of the park in its surroundings and to minimize the ecological or visual impact of the exterior over the interior of the park), and its legal area of socioeconomic influence is 175,593.40 hectares (Figure 2) - the total area of the municipalities where the National Park and its Peripheral Protection Zone are located [22].

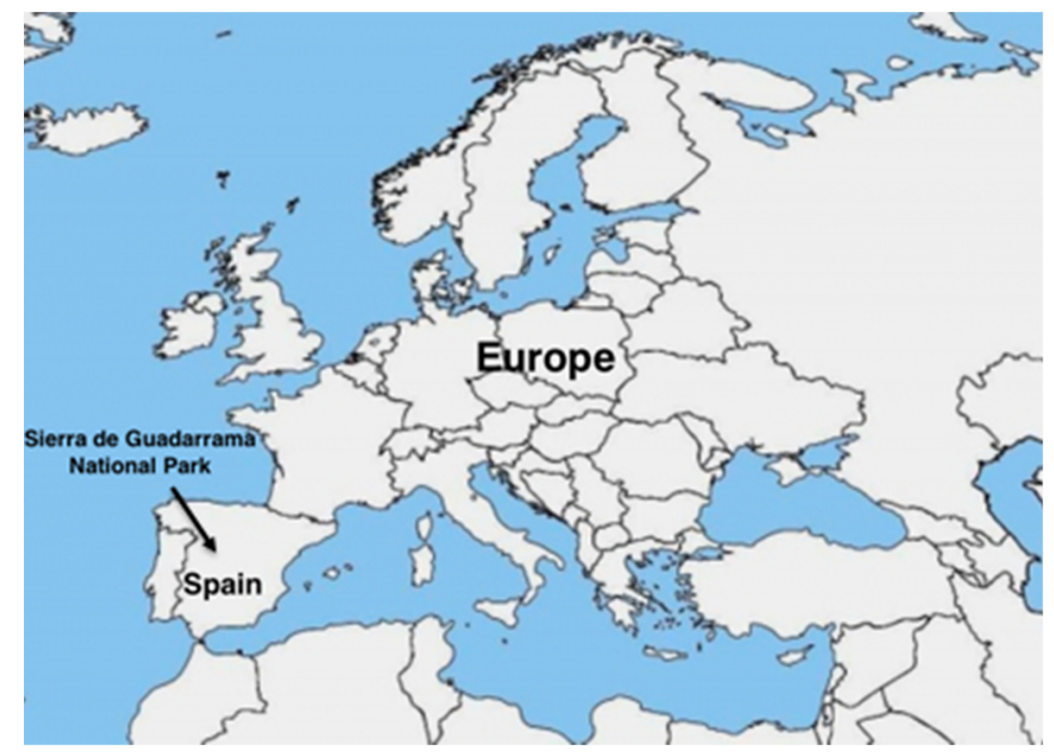

Figure 1. Sierra de Guadarrama National Park location.

The Sierra de Guadarrama has been present in Spanish literature [23] since the Middle Ages: the Archpriest of Hita (1283-1350), Cervantes (Don Quixote) (1547-1616), Lope de Vega (1562-1635), Tirso de Molina (1579-1648), Zorrilla (1607-1648), Pío Baroja (1872-1956), Cela (a Nobel Prize winner) (1916-2002), Sanchez Ferlosio (1927-2004), and Vicente Aleixandre (1898-1984), are some of the authors who have referred to it. This is not surprising, as the Sierra de Guadarrama offers grandiose and majestic scenery, and thoroughly enigmatic settings [23] (p. 24). 


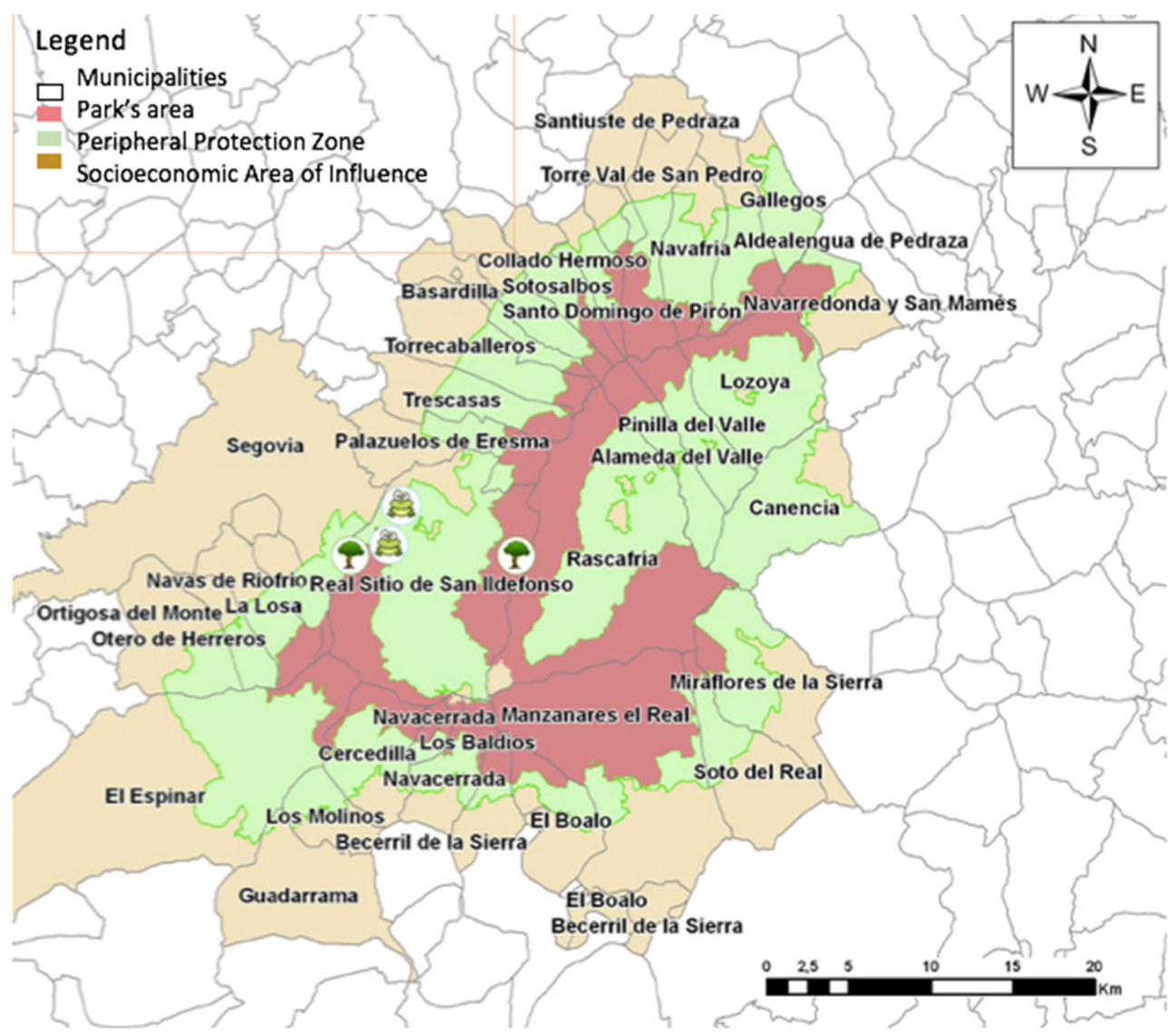

Figure 2. The park territorial limits, its zone of protection, and its area of socioeconomic influence.

The natural riches of the environs of Sierra de Guadarrama attracted the interest of kings, nobles and clergymen, who chose this area to build their palaces, fortresses, monasteries and churches, resulting in a wealth of heritage. Many of these attractions are inside or around the park, and are an addition to the park's appeal. Highlights include the Monastery of El Paular, the Castle of Manzanares, and the Royal Site of San Ildefonso [23] (p. 25).

This park is a representative sample of the natural systems of high Mediterranean mountains (Peñalara is the highest at $2428 \mathrm{~m}$ ), as are its alpine grasslands and pastures, pine and Pyrenean oak forests, peatlands, with glacier and periglacial modeling, and the presence of unique reliefs and geological elements. The main ecosystems of the park are Pinus sylvestris pine trees on siliceous soils; high mountain lakes and wetlands; formations and reliefs of mountains and high mountains; the geomorphology of granite rock that distinguishes the shape of the unique relief and landscape; gall-oak and Pyrenean oak groves; supraforestal thickets, high mountain pastures, high, woody, gravelly steppes; and forests of pine, savin juniper and juniper [24].

Its biophysical values have been internationally recognized. The park, besides being a national park, has, totally or partially, other forms of international protection. It is a Special Protection Area for Birds (SPA), parts of the park are included in two Biosphere Reserves (BR) (Cuenca Alta del Manzanares BR; Real Sitio de San Ildefonso-El Espinar BR), it is included in the International Ramsar List, and is designated a Site of Community Importance (SCI) with 25 habitats of interest, four of which are of priority. Spain occupies second place in the European Union's habitats of interest ranking and third in that of priority habitats. Sierra de Guadarrama is also characterized [25] by its floristic richness and contains a large number of threatened and/or endemic species. Its special climatic conditions and its location in the transition zone between the Eurosiberian and Mediterranean regions have favored the processes of endemism. For example, in relation to flora, 40 species of interest 
have been cataloged; 4 are on the Red List of Spanish vascular flora, 35 are in the catalog of protected flora of the region of Madrid, and 10 are in the catalog of the region of Castile and Leon. Also found here are 83 endemic plants of the Iberian Peninsula, some of them exclusive to the Central System and others to Sierra de Guadarrama.

In addition, the park has cultural values, such as the remains of traditional socioeconomic activities and trades (transhumant pastoralists, cowherds, stonecutters, oxen, charcoal workers, carters, neighbors, etc.), remnants of pastoral pastures on the top of the sierra, the ruins of shearing ranches or the brick chimneys of old sawmills, among others. These remains bring us closer to a world of traditions that influenced the local culture for centuries and shaped the territory. It is also worth mentioning the Roman road that crosses the Park, and several drovers' roads and cattle routes dating from the Middle Ages to displace the transhumant herds-millions of Merino sheep of good wool to market to other parts of the world.

Today, most of these activities have been lost, with cattle still kept for meat production. Tourism, based on the landscape, values of nature and cultural heritage, has become one of the main economic sectors in the area.

Despite its natural values, the area was not declared a national park until 2013 [24]. In order to meet the criteria to reach category II of the IUCN, this law was modified in 2014 [24]. The process to acquire this category is still ongoing. The first National Park in Spain dates back to 1916 (Covadonga National Park).

The Park belongs to two autonomous communities (regional governments). Sixty-four percent of its area corresponds to the Autonomous Community of Madrid and a little over 36 per cent belongs to the province of Segovia, in the Autonomous Community of Castile and Leon. There are 28 municipalities included in the geographical limits of the Park.

The aforementioned natural and cultural values, as well as the park's proximity-35 km-to the Madrid metropolitan area, tend to attract large numbers of people (3.8 million visits in 2014 [24]). This mass tourism produces one of the main challenges faced by the Sierra de Guadarrama National Park: the tension between the conservation of the park and the economic interests of the municipalities within the park or in the protection area surrounding it -28 included plus 34 in its area of socioeconomic influence.

Such a conflict became more visible in 2013 when the Sierra de Guadarrama was declared a National Park. Some argue that an excessive touristic focus was given to the detriment of the conservation objective [26], and that there is a lack of coordination between protection efforts and the pursuit of traditional activities [27].

The valuable ecosystem of the Sierra de Guadarrama National Park is under threat. On the one hand by global warming, to which the park is particularly vulnerable. On the other, by an existing tendency to prioritize the economic interests of local communities instead of the conservation of the park. Both pressures have the potential to interact: for example, changed land use by humans could exacerbate the effects of climate change on the natural and cultural resources of the park. Despite these, there is very little evaluation and monitoring, mitigation and adaptation to climate change [2] of the Sierra de Guadarrama National Park [28]. The current process of drafting the obligatory Master Plan for the Use and Management of the Park could be an opportunity to address climate change, particularly its socioeconomic dimensions, more directly.

\subsection{The System of Socioeconomic Indicators for the Evaluation and Monitoring of Climate Change in the Sierra} de Guadarrama National Park

The aim of designing and operating a system of socioeconomic indicators for the evaluation and monitoring of climate change in the Sierra de Guadarrama National Park responds to the need to have a sufficient set of data to monitor the short, medium and long-term effects of climate change in the social and economic sphere of this protected natural space. 
In the face of climate change, such monitoring is crucial for the development and implementation of plans [29-31], to conserve natural resources and to the living conditions of the communities dependent on these resources.

Those plans need to be based on an approach of seeking to increase the resilience of natural and social systems [32-38] in the face of considerable uncertainty about the specific changes that might occur and their timing and magnitude $[29,39]$.

To do this successfully requires consideration of a potentially wide range of valued assets, whose vulnerability to different aspects of climate change will vary, and a range of interacting biophysicial and social processes at a range of spatial scales [40].

Hence, an appropriate set of indicators needs to be carefully chosen to be able to track changes in the most important elements of these complex systems over relevant timescales and spatial scales. The collected data will enable park managers to efficiently respond to a complex and changing natural and social environment $[39,41]$.

However, managers and planners still have little guidance or training on how to address the social aspects of vulnerability to climate change in their management and planning [42,43]. This deficit can jeopardize the management strategies of these areas as well as the public support for them.

Thus, the objectives of the research presented here have been (1) the definition of a system of indicators for the evaluation and monitoring of the impact of climate change in the social and economic environment of the Sierra de Guadarrama National Park, specifying those that may be generalizable to other national parks of similar characteristics; (2) the design and development of an updated database.

\section{Methodology}

Following Land and Spilerman [44], the indicators refer to those parameters (statistics, data and all forms of evidence) that allow us to evaluate where we are and where we are going, in relation to the objectives set. The variables and indices that have the characteristic of indicators are those sensitive to changes, whether they are of social or physical nature, and trends of natural or social origin. As a whole, the system of indicators should show the relationships between the elements of the system studied and the underlying interactions [45].

To address the research objectives, we drew on a range of relevant existing sources of information relating to conservation and management of national parks and natural resources in Spain. First of all, the legal framework on which the general objectives for national parks in Spain are based; these focus primarily on the protection of their biogeophysical values [46]. However, the sustainable development of the municipalities situated within the park's area of socioeconomic influence, is also considered by law [46]. With regard to monitoring, the National Parks Network of Spain [47] proposes to develop and maintain a monitoring and evaluative system for the ecological, socioeconomic and functional aspects of each park and the Network as a whole. In addition, we have considered both the criteria and indicators for sustainable forest management in Spanish forests [48] and the evaluation of public use of national parks in Spain by the Autonomous National Parks Organization [49], the System of Indicators for the Evaluation and Monitoring of the Socio-economic Impact of the Impact of Global Change in the Picos de Europa National Park, as well as the system proposed for the Integrated Assessment of Protected Areas of the region of Madrid [16], among other sources.

Then, taking all of these aspects and arguments into account, the indicators selected were based on the following criteria. Firstly, they were selected according to the socioeconomic characteristics of the park's municipalities and the area of influence and the availability of the data [50].

Secondly, we considered the functions that the indicators should fulfill [51]: the continuous recording of the dynamics of the socioeconomic system and the analysis of the trends of change, either by natural or social causes; the improvement of the knowledge of the system, through the compilation or generation of new information regarding the social and the economic impact of climate change on the national park; the forecast for specific and/or global changes in the system, especially alterations or damage due to unexpected events; the identification, where appropriate, of the effects 
of management practices on the dynamics of social systems, and detection of undesirable effects. To do this, the research team took into consideration literature analysis, existing accessible statistical information, the park management office's annual reports, and those indicators that may be more sensitive to change.

Finally, the focus was on the concordance of the preceding two criteria with the overall goal of progressing towards the sustainable development of the communities that influence or are influenced by the National Park [52-54], according to the United Nations sustainable development goals.

The indicators developed here are the result of a selection from the many possibilities resulting from the great complexity of the natural and social systems that intertwine in protected natural spaces. This selection, made using rigorous and explicit criteria, has been necessary in order to obtain a number of indicators not too large in order to maximize the information and minimize the cost. To this end, we considered the extent to which the indicators are specific and unequivocal, easy to interpret, accessible, significant and relevant, sensitive to change, valid, verifiable and reproducible, and, above all, useful tools for action.

A balance has also been sought between the indicators of general use relating to protected natural areas and those developed for the particular case of the Sierra de Guadarrama National Park. The use of general-purpose indicators allows comparison between different protected areas and their integration into larger monitoring projects, and therefore the achievement of relevant time series.

Different indicator systems use alternative frameworks for impact analysis and sustainability [55]. In this case, we have used the Driving forces-Pressure-State-Impact-Response (DPSIR) framework, developed by the European Environment Agency (EEA) [56], which is the one used by the Spanish Ministry of Agriculture, Fishing, Food and Environment to elaborate the Water Indicators System [57].

The EEA defines "Driving forces" as "the social, demographic and economic developments in societies and the corresponding changes in lifestyles, overall levels of consumption and production patterns" [56] (p. 8). "Pressure" indicators describe the "developments in release of substances (emissions), physical and biological agents, the use of resources and the use of land" [56] (p. 9).

Pressure indicators are outside the scope of this study. Climate change is a global process that is barely affected by the activities taking place in the park, and the focus of our indicator framework is on impacts and adaptation. Therefore we do not consider it necessary to develop indicators to monitor factors (emissions of $\mathrm{CO}_{2}$ and other greenhouse gases) that cause climate change. Nor do we consider it necessary to create additional indicators to monitor climate change itself (for example changes in temperature and rainfall), as the park has weather stations with continuous meteorological meters installed and annual reports are kept.

We have focused instead on the identification of indicators for (1) the "State" category, a description of the quantity and quality of socioeconomic phenomena in the studied area; (2) the "Impacts", the changes in the social, economic and environmental dimensions, which are caused by changes in the "State" of the system; and (3) the society's "Response" to change the pressures and the state of the environment for the solution of the problem in question, as illustrated in Figure 3.

"Impact" indicators will provide data about change in the "State", but it will not be possible to establish, a priori, a causal relation, since the park's socio-ecologic system is affected by other factors as well. As the Intergovernmental Panel on Climate Change IPCC (2014) concludes, "many processes and mechanisms are well understood, but others are not. Complex interactions among multiple climatic and non-climatic influences changing over time lead to persistent uncertainties, which in turn lead to the possibility of surprises" [2] (p. 151). Further, the impact of important socioeconomic factors could emerge in the medium or long term [58], depending as well on the adopted mitigation and adaptation measures.

Even so, "for most economic sectors, the impacts of drivers such as changes in population, age structure, income, technology, relative prices, lifestyle, regulation, and governance are projected to be large relative to the impacts of climate change" [58] (p. 19). This emphasizes the importance 
of the evaluative and monitoring systems of climate change, in this case the socio-economic impact regarding the national park.

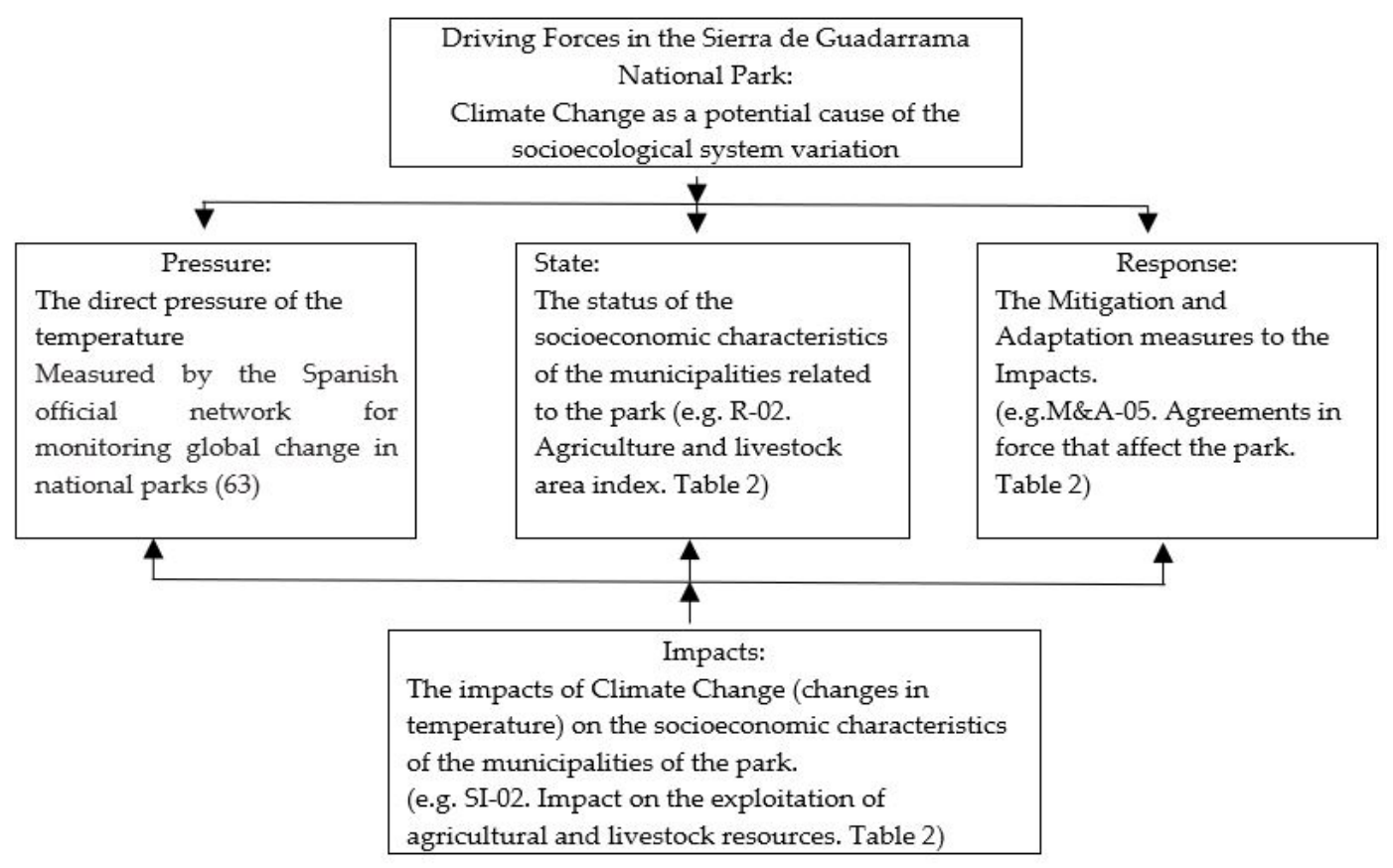

Figure 3. Example of Driving forces-Pressure-State-Impact-Response (DPSIR) scheme.

We propose a system based on a basic chain-of-causality among the indicators and their mutual dependence. This is achieved by indicating on each indicator what other indicators we consider has a relation with. The starting assumption is that the object of evaluation and monitoring is a system, formed by a series of elements interrelated to each other by different processes $[59,60]$.

Niemeijer and Groot [61] consider it important to advance the development of indicators from causal chains to causal networks, that is to say, including all systemic interrelationships between indicators. This approach enriches but also complicates the issue. In any case, it is a question of finding the appropriate balance of indicators to identify relevant trends of change for policy-making and explain the overall functioning of the system and its remoteness or approximation to sustainability [46]. This approach also makes it feasible to inform civil society and support communication with societies $[62,63]$. Finally, it must be taken into account that the use of the selected indicators requires continuous revision. The indicator here proposed are just the beginning of a monitoring system that will enable adjusting the model to better address its multi-causal dimension.

A final methodological issue regards the information used to elaborate the Sierra de Guadarrama National Park indicators. To a large extent, data has been gathered from official statistical sources. This is a limitation, as the collected data lacked in some cases the level of disaggregation necessary for some of the indicators. Even so, they have been maintained for their role in the whole system. It is expected that the information will be provided in the future.

\section{Results}

The indicators here presented have been elaborated to fit the socio-economic conditions of the Sierra de Guadarrama National Park. However, they could be adapted and used in other protected natural areas.

The category "State" has been labelled as "Receptor Environment" (RE) in this indicator system. Taking into account the socio-economic characteristics of the Sierra de Guadarrama National Park, the following categories have been proposed, differentiating "group" and "subgroup": 
1. Use of natural resources:
a. Land use
b. Agrarian resources use
c. Water use
d. Energy use
e. Waste treatment

2. Demography:
a. Population and its characteristics
b. Activity, occupation and unemployment

3. Economy:
a. Employment in productive activities
b. Tourist activity
c. Public investments
d. Income and transfers

4. Society:
a. Education
b. Health
c. Quality and living conditions

The indicators of the "Impact" (SI) are those of the future "State", which is to say, considering the changes within the time taken into consideration.

Finally, the indicators of the "Response" are those including mitigation and adaptation (M\&A) to climate change. Two levels have been differentiated: "group" and "subgroup".

\section{Governance}
a. Regulated
b. Not regulated; informal
c. National park management

2. Social and research instruments
a. Information and communication
b. Social perception
c. Training, qualification and participation
d. Social research

Table 1 has been designed for each of the indicators and includes: the name of the indicator; the frame of reference; the "group" and "subgroup"; the objectives it pursues; its justification; the measurement parameters or variables that define it; the data source; the scope and period to which they refer; and the relation with other indicators. All this is part of the necessary monitoring protocol to ensure its quality.

As a result, we have developed seventy-nine indicators altogether, which are listed on the table below. It contains thirty indicators regarding both the biophysical and socio-economic means (State) that could be affected by the impact of global and climate change (RE); twenty indicators regarding the future socioeconomic "Impact" of climate change (SI); twenty-nine indicators regarding the measures (Response) to mitigate and to adapt to climate change (M\&A). All these indicators are available on the internet and can be accessed following the links provided in the Supplementary Materials at the end of this article.

Table 2 shows a list of all the indicators developed and the indicators with which they are related. 
Table 1. Example of an indicator.

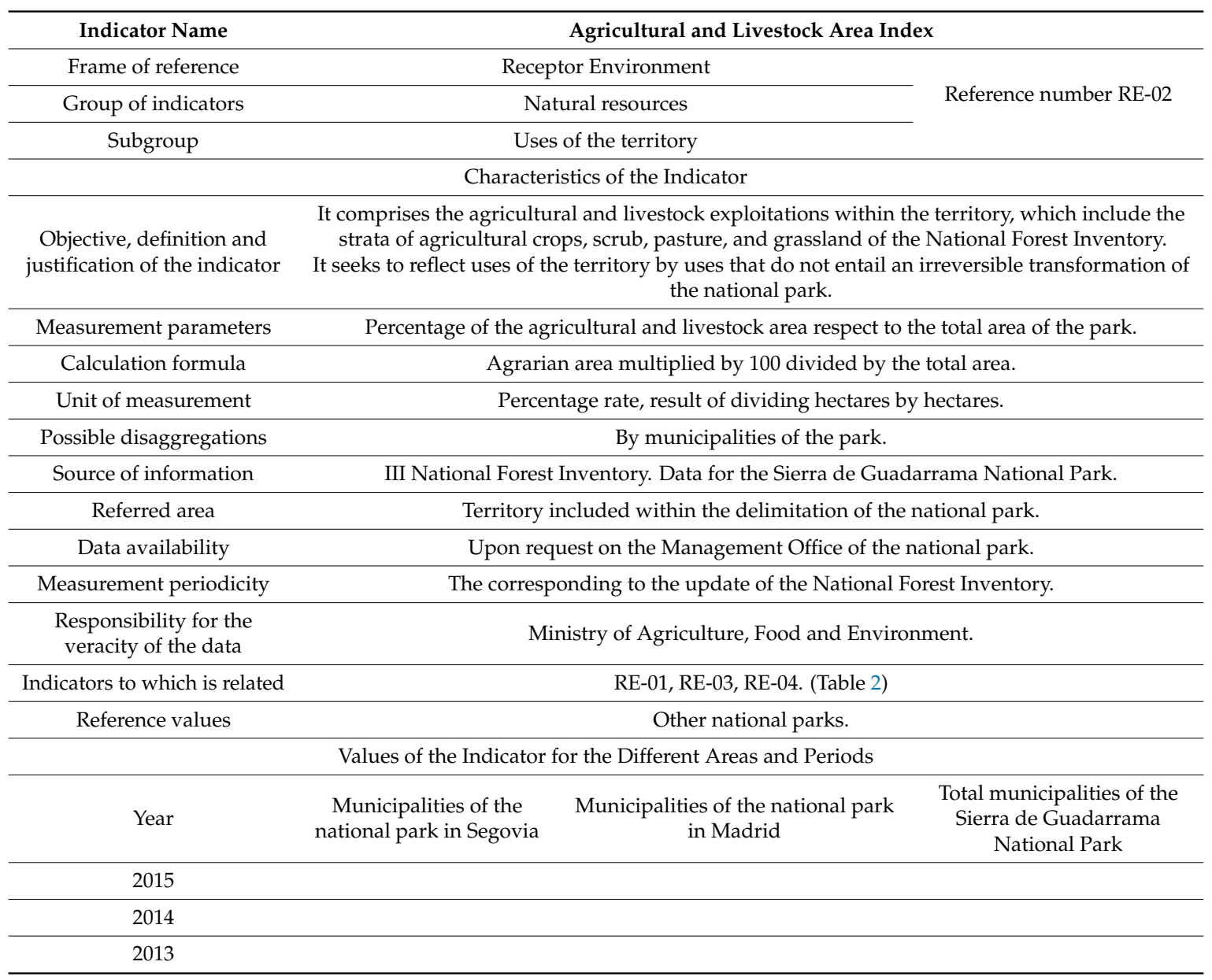

Comments: Model of the Indicator Data-Sheet. Its quantification would require an ad-hoc investigation, not included in the scope of this work. 
Table 2. Indicators for the Socio-Economic Monitoring and Evaluation System of Climate Change of the Sierra de Guadarrama National Park.

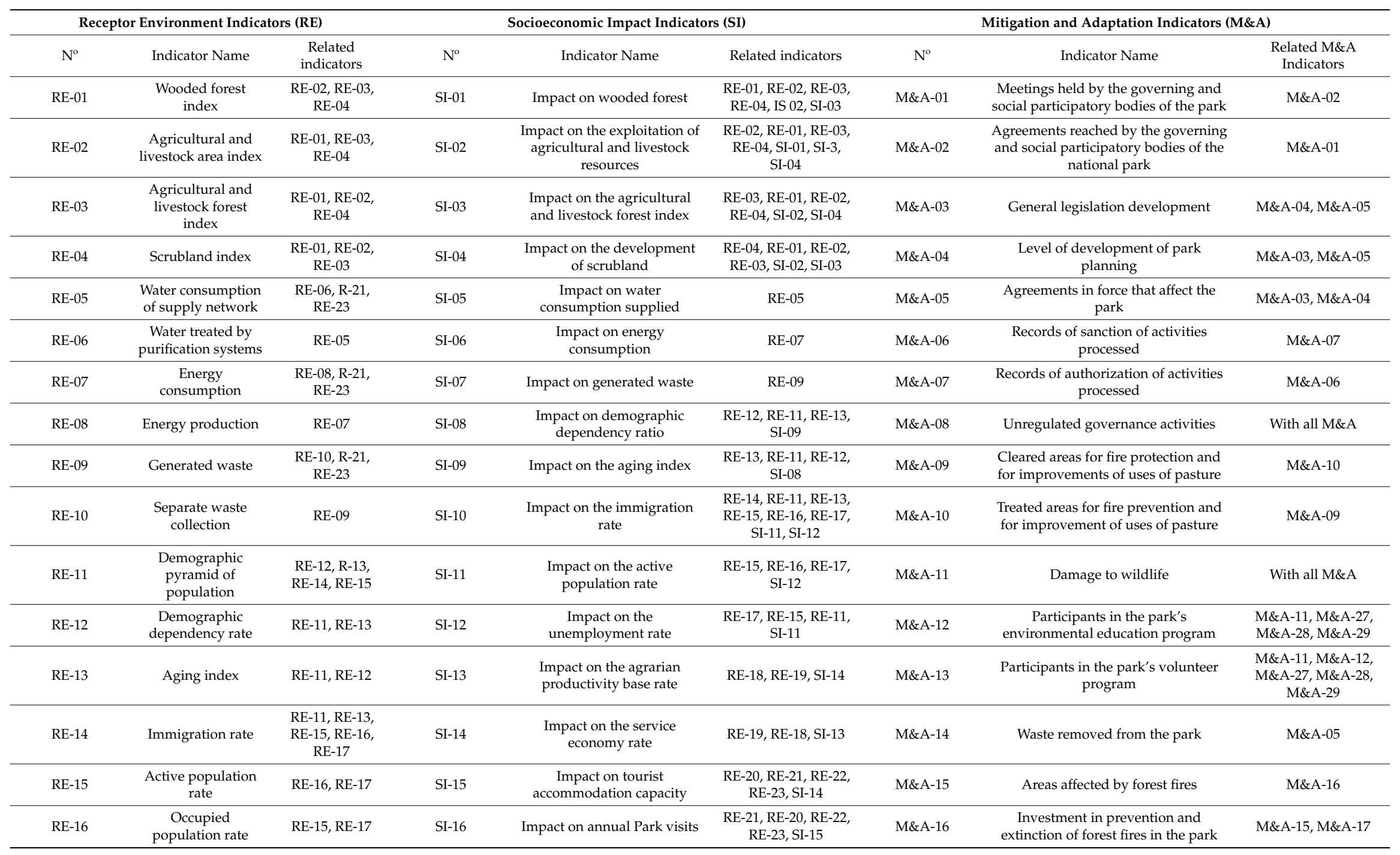


Table 2. Cont.

\begin{tabular}{|c|c|c|c|c|c|c|c|c|}
\hline \multicolumn{3}{|c|}{ Receptor Environment Indicators (RE) } & \multicolumn{3}{|c|}{ Socioeconomic Impact Indicators (SI) } & \multicolumn{3}{|c|}{ Mitigation and Adaptation Indicators (M\&A) } \\
\hline RE-17 & $\begin{array}{c}\text { Registered } \\
\text { unemployment }\end{array}$ & RE-15, RE-11 & SI-17 & $\begin{array}{l}\text { Impact on the seasonality } \\
\text { of visits }\end{array}$ & $\begin{array}{l}\text { RE-22, RE-20, RE-21, } \\
\text { RE-23, SI-16 }\end{array}$ & M\&A-17 & Public investments in the park & M\&A-15, M\&A-16 \\
\hline RE-18 & $\begin{array}{l}\text { Agrarian } \\
\text { productivity base } \\
\text { rate }\end{array}$ & RE-19 & SI-18 & $\begin{array}{l}\text { Impact on the touristic uses } \\
\text { of housing }\end{array}$ & $\begin{array}{l}\text { RE-23, RE-20, RE-21, } \\
\text { RE-22, SI-16 }\end{array}$ & $M \& A-18$ & $\begin{array}{l}\text { Grants given in the municipalities of } \\
\text { the park }\end{array}$ & M\&A-16 \\
\hline RE-19 & $\begin{array}{l}\text { Service economy } \\
\text { rate }\end{array}$ & RE-18 & SI-19 & $\begin{array}{l}\text { Impact on public investment } \\
\text { per capita }\end{array}$ & $\begin{array}{l}\text { RE-24, RE-25, RE-26, } \\
\text { SI-20 }\end{array}$ & M\&A-19 & $\begin{array}{l}\text { Compensation for the cease of } \\
\text { activities incompatible with the } \\
\text { regime of the park }\end{array}$ & M\&A-17 \\
\hline RE-20 & $\begin{array}{l}\text { Tourist } \\
\text { accommodation } \\
\text { capacity }\end{array}$ & $\begin{array}{l}\text { RE-21, RE-22, } \\
\text { RE-23 }\end{array}$ & SI-20 & $\begin{array}{l}\text { Impact on health } \\
\text { infrastructure }\end{array}$ & $\begin{array}{l}\text { RE-24, RE-25, RE-28, } \\
\text { RE-11, RE-13, SI-19 }\end{array}$ & $\mathrm{M} \& \mathrm{~A}-20$ & People attended at the visitor centers & M\&A-20, M\&A-21 \\
\hline RE-21 & Park visits & $\begin{array}{c}\text { RE-20, RE-22, } \\
\text { RE-23 }\end{array}$ & & & & $\mathrm{M} \& \mathrm{~A}-21$ & School group visits to the park & M\&A-22, M\&A-23 \\
\hline RE-22 & $\begin{array}{c}\text { Seasonality of Park } \\
\text { visits }\end{array}$ & $\begin{array}{l}\text { RE-20, RE-21, } \\
\text { RE-23 }\end{array}$ & & & & M\&A-22 & Non-school group visits to the park & M\&A-20 \\
\hline RE-23 & $\begin{array}{l}\text { Secondary uses of } \\
\text { housing }\end{array}$ & $\begin{array}{l}\text { RE-20, RE-21, } \\
\text { RE-22 }\end{array}$ & & & & $\mathrm{M} \& \mathrm{~A}-23$ & $\begin{array}{l}\text { Brochures and other information } \\
\text { formats edited by the park }\end{array}$ & M\&A-24 \\
\hline RE-24 & $\begin{array}{l}\text { Public investment } \\
\text { per capita }\end{array}$ & RE-25, RE-26 & & & & M\&A-24 & $\begin{array}{l}\text { Specific publications related to global } \\
\text { and climate change edited by the park }\end{array}$ & M\&A-25 \\
\hline RE-25 & $\begin{array}{c}\text { Municipal } \\
\text { investment per } \\
\text { capita }\end{array}$ & RE-24, RE-26 & & & & $\mathrm{M} \& \mathrm{~A}-25$ & $\begin{array}{l}\text { Social perception of global and climate } \\
\text { change; Social participation }\end{array}$ & $\begin{array}{l}\text { M\&A-11, M\&A-12, } \\
\text { M\&A-26, M\&A-27, } \\
\text { M\&A-28, M\&A-29 }\end{array}$ \\
\hline RE-26 & $\begin{array}{c}\text { Municipal } \\
\text { indebtedness per } \\
\text { capita }\end{array}$ & RE-24, RE-25 & & & & M\&A-26 & $\begin{array}{l}\text { Training and enabling activities about } \\
\text { global and climate change }\end{array}$ & $\begin{array}{l}\text { M\&A-12, M\&A-13, } \\
\text { M\&A-28, M\&A-30 }\end{array}$ \\
\hline RE-27 & $\begin{array}{l}\text { Rate of university } \\
\text { graduates }\end{array}$ & RE-11 & & & & $\mathrm{M} \& \mathrm{~A}-27$ & $\begin{array}{l}\text { Research on the impact of global and } \\
\text { climate change on the biogeophysical } \\
\text { environment of the park }\end{array}$ & M\&A-28 \\
\hline RE-28 & $\begin{array}{c}\text { Health } \\
\text { infrastructure index }\end{array}$ & $\begin{array}{l}\text { RE-11, RE-13, } \\
\text { RE-24, RE-25 }\end{array}$ & & & & $\mathrm{M} \& \mathrm{~A}-28$ & $\begin{array}{l}\text { Research on the impact of global and } \\
\text { climate change on the social and } \\
\text { economic environment of the park }\end{array}$ & M\&A-29 \\
\hline RE-29 & Home equipment & RE-23 & & & & M\&A-29 & $\begin{array}{l}\text { Visits to the website of the National } \\
\text { Parks Autonomous Body within the } \\
\text { section monitoring global change in } \\
\text { the network of national parks }\end{array}$ & $\begin{array}{l}\text { M\&A-12, M\&A-13, } \\
\text { M\&A 27, M\&A-28 }\end{array}$ \\
\hline RE-30 & $\begin{array}{l}\text { Elderly population } \\
\text { living alone }\end{array}$ & RE-13 & & & & & & \\
\hline
\end{tabular}




\section{Discussion}

The first general conclusion is that the corpus of scientific and empirical knowledge on the social and economic impact of climate change on national parks is scant. However, the study of the socioeconomic impact of climate change in national parks is relevant because climate change is one of the most important challenges faced by today's society. Moreover, climate impacts on people in and around parks, and people's response to such impacts could also affect the natural values of the parks.

Thus, it is considered necessary to evaluate and monitor these impacts, with a systematic scientific approach aimed at understanding parks interconnected biophysical and social systems. This requires the development of more ad hoc theoretical and methodological tools for national parks. This work is oriented in that sense, although limited to indicators and data that nevertheless need to be tested and adjusted in the future.

For diverse reasons, the indicators elaborated for the Sierra de Guadarrama National Park vary in their detail, including the lack of sufficiently disaggregated statistical information and the necessary primary research that qualitative indicators require. This primary research is particularly important in order to extend the system to process indicators, limited in this work as well as in many of these features. Such indicators of processes make it possible to examine social phenomena, like relationships between social groups or social perception of trends on sustainability in the area of study. The system of indicators we propose will have to be adjusted in the future, as the processes of interaction of the biophysical and social systems of the Sierra de Guadarrama National Park are better known. The same will be also necessary in the other national parks with similar characteristics.

A system of indicators for the monitoring and evaluation of the social and economic impacts of climate change has the potential to go beyond simple reporting. It can provide information on whether the situation improves or worsens, recedes or progresses, increases or decreases.

Socio-ecological systems generally are multi-causal and different depending the characteristics of the area. Thus, it cannot be a priori determined whether such changes have been caused by climate change or by any other factor or combination of factors. Nonetheless, continuous evaluation will allow to deepen the understanding of the causal relationships between changes in climatic conditions, changes in the socio-ecological system and changes in natural and cultural values of the park. For example, climate change is a direct cause of drought termed "meteorological drought", in addition to human action or "hydric drought" (water infrastructures, responsible water human use or consumption, etc.), which could also have a relevant impact on the economy (agricultures, industry, tourism, etc.), environment (evolution of fauna and flora, territory, etc.) and population's living conditions (consumption, transport, live styles, etc.) and environmental values and attitudes (response dimension). However, this needs to be tested over time.

Ideally, the information provided by a system of socio-economic indicators relating to climate change can be integrated into management planning of national parks to improve decision-making. Moreover, a study on indicators could be the catalyst for the development of comprehensive climate change adaptation plans for individual national parks and protected area networks, which is still limited or non-existent in most national parks in Spain and many other parts of the world.

\section{Conclusions}

In conclusion, the interpretation of changes in the monitoring process of complex climate-related changes in protected areas is a major challenge. The evaluation of the interactions between climate change and the socio-ecological changes in the park and its area of influence requires a holistic approach and a sufficient time-series of data. The set of socio-economic indicators we have developed provides a framework for collecting and interpreting such, and so will help to inform adaptation planning for the Sierra de Guadarrama National Park. The approach we have taken could also be applied in other similar national parks. 
Supplementary Materials: The seventy-nine indicators are available online at: http://portal.uc3m.es/ portal/page/portal/grupos_investigacion/sociologia_cambio_climatico/Sociology_of_Climate_Change_ and_Sustainable_Development/Receptor\%20Environment\%20Indicators.\%20Sierra\%20de\%20Guadarrama\% 20Na.pdf; http://portal.uc3m.es/portal/page/portal/grupos_investigacion/sociologia_cambio_climatico/ Sociology_of_Climate_Change_and_Sustainable_Development/Impact \%20Indicators.\%20Sierra\%20de \% 20Guadarrama\%20National\%20Park.pdf; http://portal.uc3m.es/portal/page/portal/grupos_investigacion/ sociologia_cambio_climatico/Sociology_of_Climate_Change_and_Sustainable_Development/Mitigation\% 20and\%20Adaptation\%20Indicators.\%20Sierra\%20de\%20Guadarra.pdf.

Acknowledgments: This research was funded by Fundación Biodiversidad. We did not received funds for covering the costs to publish in open access.

Author Contributions: Both authors directed the research project. Iván López and Mercedes Pardo have contributed to the draft of the paper.

Conflicts of Interest: The author declares no conflict of interest.

\section{References}

1. UN. United Nations Framework Convention on Climate Change; United Nations: New York, NY, USA, 1992.

2. IPCC. Climate Change: Synthesis Report; WMO: Geneva, Switzerland, 2014; p. 151. ISBN 978-92-9169-143-2.

3. Rannow, S.; Macgregor, N.A.; Albrecht, J.; Crick, H.Q.; Förster, M.; Heiland, S.; Janauer, G.; Morecroft, M.D.; Neubert, M.; Sarbu, A.; et al. Managing protected areas under climate change: Challenges and priorities. Environ. Manag. 2014, 54, 732-743. [CrossRef] [PubMed]

4. Zamora, R. Las Áreas protegidas como Observatorios del Cambio Global. Ecosistemas 2010, 19, 1-4.

5. Fancy, S.G.; Bennetts, R.E. Institutionalizing an effective long-term monitoring program in the U.S. National Park Service. In Design and Analysis of Long-Term Ecological Monitoring Studies; Gitzen, R.A., Millspaugh, J.J., Cooper, A.B., Licht, D.S., Eds.; Cambridge University Press: Cambridge, UK, 2012; pp. 481-497.

6. Hansen, A.J.; Piekielek, N.; Davis, C.; Haas, J.; Theobald, D.M.; Gross, J.E.; Monahan, W.B.; Olliff, T.; Running, S.W. Exposure of U.S. National Parks to land use and climate change 1900-2100. Ecol. Appl. 2014, 24, 484-502. [CrossRef] [PubMed]

7. Hansen, A.J.; Monahan, W.; Theobald, D.M.; Olliff, S.T. Climate Change in Wildlands: Pioneering Approaches to Science and Management; Island Press: Washington, DC, USA, 2016; ISBN 9781610917124.

8. Löeffler, J.; Anschlag, K.; Baker, B.; Finch, O.D.; Diekkrueger, B.; Wundram, D.; Schröder, B.; Pape, R.; Lundberg, A. Mountain ecosystem response to global change. Erdkunde 2011, 65, 189-213. [CrossRef]

9. Tiwari, P.C.; Joshi, B. Global Change and Mountains: Consequences, Responses and Opportunities. In Impact of Global Changes on Mountains: Responses and Adaptation; Grover, V.I., Borsdorf, A., Breuste, J.H., Tiwari, P.C., Frangetto, F., Eds.; CRC Press: London, UK; New York, NY, USA, 2014; pp. 79-136. ISBN 978-1-4822-0890-0.

10. Lockwood, M.; Worboys, G.; Kothari, A. (Eds.) Managing Protected Areas: A Global Guide; Routledge: Milton Park, UK, 2012; ISBN 978-1-84407-303-3.

11. Cook, C.N.; Mascia, M.B.; Schwartz, M.W.; Possingham, H.P.; Fuller, R.A. Achieving conservation science that bridges the knowledge-action boundary. Conserv. Biol. 2013, 27, 669-678. [CrossRef] [PubMed]

12. Kremen, C. Assessing the Indicator Properties of Species Assemblages for Natural Areas Monitoring. Ecol. Appl. 1992, 2, 203-217. [CrossRef] [PubMed]

13. Noss, R.F. Assessing and monitoring forest biodiversity: A suggested framework and indicators. For. Ecol. Manag. 1999, 115, 135-146. [CrossRef]

14. Hockings, M.; Stolton, S.; Leverington, F.; Dudley, N.; Courrau, J. Evaluating Effectiveness: A Framework for Assessing the Management of Protected Areas, 2nd ed.; IUCN: Gland, Switzerland; Cambridge, UK, 2006; ISBN 978-2-8317-0939-0.

15. Leverington, F.; Costa, K.L.; Pavese, H.; Lisle, A.; Hockings, M. A global analysis of protected area management effectiveness. Environ. Manag. 2010, 46, 685-698. [CrossRef] [PubMed]

16. Rodríguez-Rodríguez, D.; Martínez-Vega, J. Results of the implementation of the System for the Integrated Assessment of Protected Areas (SIAPA) to the protected areas of the Autonomous Region of Madrid (Spain). Ecol. Indic. 2013, 34, 210-220. [CrossRef] 
17. Fancy, S.G.; Gross, J.E.; Carter, S.L. Monitoring the condition of natural resources in US national parks. Environ. Monit. Assess. 2009, 151, 161-174. [CrossRef] [PubMed]

18. Cutter, S.L.; Boruff, B.J.; Shirley, W.L. Social vulnerability to environmental hazards. Soc. Sci. Q. 2003, 84, 242-261. [CrossRef]

19. Adger, W.N.; Brooks, N.; Bentham, G.; Agnew, M.; Eriksen, S. New Indicators of Vulnerability and Adaptive Capacity; Technical Report 7; Tyndall Centre for Climate Change Research: Norwich, UK, 2004.

20. Mitchell, R.; Parkins, J. The challenge of developing social indicators for cumulative effects assessment and land use planning. Ecol. Soc. 2011, 16, 29:1-29:14. [CrossRef]

21. Petrova, S. Communities in Transition: Protected Nature and Local People in Eastern and Central Europe; Routledge: Milton Park, UK, 2014; ISBN 978-1-13-825130-4.

22. Ley $7 / 2013$, de 25 de junio, de Declaración del Parque Nacional de la Sierra de Guadarrama. Available online: https:/ / www.boe.es/diario_boe/txt.php?id=BOE-A-2013-6900 (accessed on 11 January 2018).

23. Parque Nacional Sierra de Guadarrama. Mundo del Agrónomo 2015, 29, 24-26. Available online: http: / / www.agronomoscentro.org/images/mda/mda29.pdf (accessed on 24 August 2017).

24. Parque Nacional Sierra de Guadarrama. Available online: http:/ / www.parquenacionalsierraguadarrama. es/en/ (accessed on 25 August 2017).

25. Ramos de Armas, F.J. El Parque Nacional de la Sierra de Guadarrama. Ambienta: La revista del Ministerio de Medio Ambiente 2013, 103, 4-9.

26. Nieto, N.; Díez, R. Sierra de Guadarrama, un Parque Nacional liberal: Más marca turística que conservación. El Ecologista 2014, 82, 28-29.

27. Campos Palacín, P.; Carrera Troyano, M. Crítica de la exclusión del aprovechamiento de recursos naturales en los parques nacionales españoles. Principios de Economía Política 2007, 8, 39-58.

28. Rodríguez-Rodríguez, D.; Martínez-Vega, J. What should be evaluated from a manager's perspective? Developing a salient protected area effectiveness evaluation system for managers and scientists in Spain. Ecol. Indic. 2016, 64, 289-296.

29. Doak, D.F.; Estes, J.A.; Halpern, B.S.; Jacob, U.; Lindberg, D.R.; Lovvorn, J.; Monson, D.H.; Tinker, M.T.; Williams, T.M.; Wootton, J.T.; et al. Understanding and predicting ecological dynamics: Are major surprises inevitable. Ecology 2008, 89, 952-961. [CrossRef] [PubMed]

30. Millar, C.I.; Stephenson, N.L.; Stephens, S.L. Climate change and forests of the future: Managing in the face of uncertainty. Ecol. Appl. 2007, 17, 2145-2151. [CrossRef] [PubMed]

31. Baron, J.S.; Allen, C.D.; Fleishman, E.; Gunderson, L.; Mckenzie, D.; Meyerson, L.; Oropeza, J.; Stephenson, N. National parks. In Preliminary Review of Adaptation Options for Climate-Sensitive Ecosystems and Resources. A Report by the U.S. Climate Change Science Program and the Subcommittee on Global Change Research; Julius, S.H., West, J.M., Eds.; Environmental Protection Agency: Washington, DC, USA, 2008; pp. 1-68.

32. Naughton-Treves, L.; Holland, M.B.; Brandon, K. The role of protected areas in conserving biodiversity and sustaining local livelihoods. Annu. Rev. Environ. Resour. 2005, 30, 219-252. [CrossRef]

33. West, P.; Igoe, J.; Brockington, D. Parks and peoples: The social impact of protected areas. Annu. Rev. Anthropol. 2006, 35, 251-277. [CrossRef]

34. Berkes, F. Community-based conservation in a globalized world. Proc. Natl. Acad. Sci. USA 2007, 104, 15188-15193. [CrossRef] [PubMed]

35. Budruk, M.; Phillips, R. (Eds.) Quality-of-Life Community Indicators for Parks, Recreation and Tourism Management; Springer: London, UK, 2011; Volume 43, ISBN 978-94-007-3445-6.

36. Holling, C.S. Resilience and stability of ecological systems. Annu. Rev. Ecol. Syst. 1973, 4, 1-23. [CrossRef]

37. Welsh, M. Resilience and responsibility: Governing uncertainty in a complex world. Geogr. J. 2014, 180, 15-26. [CrossRef]

38. Tanner, T.; Lewis, D.; Wrathall, D.; Bronen, R.; Cradock-Henry, N.; Huq, S.; Lawless, C.; Nawrotzki, R.; Prasad, V.; Rahman, M.A.; et al. Livelihood resilience in the face of climate change. Nat. Clim. Chang. 2015, 5, 23-26. [CrossRef]

39. Baron, J.S.; Gunderson, L.; Allen, C.D.; Fleishman, E.; McKenzie, D.; Meyerson, L.A.; Oropeza, J.; Stephenson, N. Options for national parks and reserves for adapting to climate change. Environ. Manag. 2009, 44, 1033-1042. [CrossRef] [PubMed]

40. Glick, P.; Stein, B.; Edelson, N.A. Scanning the Conservation Horizon: A Guide to Climate Change Vulnerability Assessment; National Wildlife Federation: Washington, DC, USA, 2010. 
41. Williamson, T.B.; Price, D.T.; Beverly, J.L.; Bothwell, P.M.; Parkins, J.R.; Patriquin, M.N.; Pearce, C.; Stedman, R.C.; Volney, W.J.A. A Framework for Assessing Vulnerability of Forest-Based Communities to Climate Change; Natural Resources Canada, Canadian Forest Service, Northern Forestry Centre: Edmonton, AB, Canada, 2007; ISBN 978-0-662-47044-1.

42. Rodríguez-Rodríguez, D.; Martínez-Vega, J. Proposal of a system for the integrated and comparative assessment of protected areas. Ecol. Indic. 2012, 23, 566-572. [CrossRef]

43. Fischer, A.P.; Paveglio, T.; Carroll, M.; Murphy, D.; Brenkert-Smith, H. Assessing social vulnerability to climate change in human communities near public forests and grasslands: A framework for resource managers and planners. J. For. 2013, 111, 357-365. [CrossRef]

44. Land, K.C.; Spilerman, S. (Eds.) Social Indicator Models; Russel Sage Foundation: New York, NY, USA, 1975; ISBN 978-0-87154-505-3.

45. Force, J.E.; Machlis, G.E. The human ecosystem part II: Social indicators in ecosystem management. Soc. Nat. Resour. 1997, 10, 369-382. [CrossRef]

46. Ley 30/2014, de 3 de Diciembre, de Parques Nacionales. Available online: https://www.boe.es/boe/dias / 2014/12/04/pdfs/BOE-A-2014-12588.pdf (accessed on 25 August 2017).

47. Royal Decree 389/2016, de 22 de octubre, Plan Director de la Red de Parques Nacionales. Available online: https:/ / www.boe.es/boe/dias/2016/10/24/pdfs/BOE-A-2016-9690.pdf (accessed on 29 August 2017).

48. MAGRAMA. Available online: http://www.mapama.gob.es/es/biodiversidad/publicaciones/informe_ castellano_criterios_indicarores_gestion_forestal_sostenible_bosques_2012_tcm7-260632.pdf (accessed on 24 August 2017).

49. Muñoz Santos, M.; Benayas Del Álamo, J. El uso Público en la Red de Parques Nacionales de España: Una Propuesta de Evaluación; Organismo Autónomo Parques Nacionales: Madrid, Spain, 2012; ISBN 978-84-8014-827-6.

50. Instituto Nacional de Estadística. Lista Completa de Operaciones. 2016. Available online: http://www.ine. es/dyngs/INEbase/listaoperaciones.htm (accessed on 11 January 2018).

51. Jones, D.A.; Hansen, A.J.; Bly, K.; Doherty, K.; Verschuyl, J.P.; Paugh, J.I.; Carle, R.; Story, S.J. Monitoring land use and cover around parks: A conceptual approach. Remote Sens. Environ. 2009, 113, 1346-1356. [CrossRef]

52. Beckley, T.; Parkins, J.; Stedman, R. Indicators of forest-dependent community sustainability: The evolution of research. For. Chron. 2002, 78, 626-636. [CrossRef]

53. Gough, A.D.; Innes, J.L.; Allen, S.D. Development of common indicators of sustainable forest management. Ecol. Indic. 2008, 8, 425-430. [CrossRef]

54. Akamani, K.A. Community resilience model for understanding and assessing the sustainability of forest-dependent communities. Hum. Ecol. Rev. 2012, 19, 99-109.

55. Singh, R.K.; Murty, H.R.; Gupta, S.K.; Dikshit, A.K. An overview of sustainability assessment methodologies. Ecol. Indic. 2012, 15, 281-299. [CrossRef]

56. Smeets, E.; Weterings, R. Environmental Indicator: Typology and Overview; Technical Report 25; European Environment Agency: Copenhagen, Denmark, 1999.

57. Ministerio de Agricultura, Pesca, Alimentacion y Medio Ambiente. Water Indicators System. Available online: http:/ / www.mapama.gob.es/es/agua/temas/planificacion-hidrologica/sia-/indicadores.aspx (accessed on 29 January 2018).

58. IPCC. Summary for policymakers. In Climate Change 2014: Impacts, Adaptation, and Vulnerability. Part A: Global and Sectoral Aspects. Contribution of Working Group II to the Fifth Assessment Report of the Intergovernmental Panel on Climate Change; Field, C.B.V.R., Barros, D.J., Dokken, K.J., Mach, M.D., Mastrandrea, T.E., Bilir, M., Chatterjee, K.L., Ebi, Y.O., Estrada, R.C., Genova, B., et al., Eds.; Cambridge University Press: Cambridge, UK; New York, NY, USA, 2014; pp. 1-32.

59. Machlis, G.E.; Force, J.E.; Burch, W.R., Jr. The human ecosystem part I: The human ecosystem as an organizing concept in ecosystem management. Soc. Nat. Resour. 1997, 10, 347-367. [CrossRef]

60. Weber, M.; Krogman, N.; Antoniuk, T. Cumulative effects assessment: Linking social, ecological, and governance dimensions. Ecol. Soc. 2012, 17, 22:1-22:7. [CrossRef]

61. Niemeijer, D.; De Groot, R.S. Framing environmental indicators: Moving from causal chains to causal networks. Environ. Dev. Sustain. 2008, 10, 89-106. [CrossRef] 
62. OECD. Environmental Indicators: Towards Sustainable Development; OECD: Paris, France, 2001.

63. Red de Seguimiento del Cambio Global en la Red de Parques Nacionales. Ministerio de Agricultura y Pesca, Alimentación y Medio Ambiente. Available online: http:/ /www.mapama.gob.es/es/red-parquesnacionales/red-seguimiento/resultados-2015-rscg_tcm7-449653.pdf (accessed on 25 November 2017). 